\title{
PENGARUH BUDAYA ORGANISASI DAN KEPUASAN KERJA TERHADAP KINERJA KARYAWAN DENGAN KOMITMEN ORGANISASI SEBAGAI VARIABEL INTERVENING
}

\author{
(THE INFLUENCE OF ORGANIZATIONAL CULTURE AND WORK \\ SATISFACTION ON EMPLOYEE PERFORMANCE WITH \\ ORGANIZATIONAL COMMITMENTS AS INTERVENING VARIABLES)
}

Oleh:

Maya Kharishma ${ }^{1)}$; Sri Lestari Prasilowati2); Eka Avianti Ayuningtyas ${ }^{3)}$

Sekolah Tinggi Ilmu Ekonomi IPWI Jakarta1,2,3)

maya@springfield.sch.id ${ }^{1)}$; widiyantoterry@yahoo.com ${ }^{2}$; eka.avianti@gmail.com $^{3}$ )

Submit: 15 Sep 2019

Review: 15 Sep 2019

Accept: 17 Sep 2019

\section{ABSTRACT}

Organizational culture, job satisfaction and organizational commitment in a company or organization are variables that are thought to be relatively significant in influencing the performance of Springfield School Cibubur employees. In order to prove the presence or absence of the influence of organizational culture and job satisfaction on performance with organizational commitment as an intervening variable, research was conducted with the aim of analyzing the presence of influence of these three variables on the performance of Springfield School Cibubur employees.

The study was conducted at Springfield Cibubur school by taking saturated samples from the whole employee population excluding researcher. The questionnaire was distributed to 59 respondents with returned rate of $100 \%$. Margin of error of $5 \%$ is used for the research.

The study produced 5 main findings as follows: (1)Organizational culture has influence on performance of Springfield School Cibubur employees; (2) Job satisfaction has no influence on performance of Springfield School Cibubur employees; (3) Organizational culture has influence on organizational commitment of Springfield School Cibubur employees; (4) Job satisfaction has no influence on organizational commitment of Springfield School Cibubur employees; (5) Organizational commitment has no influence on performance of Springfield School Cibubur employees.

Keywords:

organizational culture, job satisfaction, organizational commitment, employee performance.

\begin{abstract}
ABSTRAK
Budaya organisasi, kepuasan kerja dan komitmen organisasi dalam suatu perusahaan atau organisasi merupakan variabel yang diduga relatif signifikan mempengaruhi kinerja karyawan sekolah Springfield Cibubur. Untuk membuktikan ada atau tidaknya pengaruh budaya organisasi dan kepuasan kerja terhadap kinerja dengan komitmen organisasi sebagai variabel intervening, maka
\end{abstract}


dilakukan penelitian dengan tujuan untuk menganalisa adanya pengaruh dari ketiga variabel tersebut terhadap kinerja karyawan pada sekolah Springfield Cibubur.

Penelitian dilakukan di sekolah Springfield Cibubur dengan pengambilan sampel jenuh terhadap seluruh populasi karyawan, dengan tidak mengikutsertakan peneliti. Kuesioner diberikan kepada 59 responden dengan tingkat pengembalian 100\%. Untuk penelitian ini digunakan margin of error $5 \%$.

Penelitian menghasilkan 5 temuan utama sebagai berikut: (1) Budaya organisasi berpengaruh terhadap kinerja karyawan sekolah Springfield Cibubur; (2) Kepuasan kerja tidak berpengaruh terhadap kinerja karyawan sekolah Springfield Cibubur; (3) Budaya organisasi berpengaruh terhadap komitmen organisasi karyawan sekolah Springfield Cibubur; (4) Kepuasan kerja tidak berpengaruh terhadap komitmen organisasi karyawan sekolah Springfield Cibubur; (5) Komitmen organisasi tidak berpengaruh terhadap kinerja karyawan sekolah Springfield Cibubur.

Kata kunci:

Budaya organisasi, kepuasan kerja, komitmen organisasi, kinerja karyawan.

\section{PENDAHULUAN}

Budaya organisasi adalah salah satu strategi untuk dapat memberikan motivasi karyawan dalam usaha mencapai kinerja yang maksimal, karena budaya organisasi yang baik akan memberikan kondisi dan situasi yang sesuai untuk karyawan dalam bekerja apabila budaya tersebut dipandang cocok dan mampu mendukung karyawan didalam pengembangan dirinya dan menopang kese-jahteraannya. Budaya organisasi yang baik secara langsung berhubungan dengan kinerja dari suatu organisasi yang juga akan ikut meningkat.

Hal ini sesuai dengan temuan beberapa penelitian terdahulu yang membuktikan adanya pengaruh positif dari budaya organisasi terhadap kinerja, seperti pada penelitian Tenggara $\mathrm{dkk}$ (2016), Pratama (2016) dan Adhika dkk (2014).

Kinerja karyawan berhubungan dengan kepuasan kerja. Kepuasan kerja adalah reaksi yang bersifat mempengaruhi sikap seseorang terhadap berbagai segi pekerjaannya. Kepuasaan kerja yang tinggi dipercaya akan mempengaruhi peningkatan kinerja individu. Kepuasan kerja yang rendah menimbulkan banyak dampak negatif seperti tingkat ketidak hadiran yang tinggi, pindah kerja, malas bekerja, dan sebagainya. Hal ini berakibat buruk bagi perusahaan walaupun kerugian tidak terlalu jelas terlihat. Sebaliknya, kepuasan kerja yang tinggi memberikan pengaruh yang positif dan dinamis sehingga mampu memberikan keuntungan bagi tenaga kerja itu sendiri. Pembicaraan positif tetang organisasi akan lebih terlihat dari pekerja yang memiliki kepuasan kerja yang tinggi.

Kondisi inilah yang sangat diharapkan oleh manajemen perusahaan atau organisasi (Krisdiyanto, 2010). Organisasi yang sukses memerlukan pekerja yang dapat mengerjakan melebihi dari tugas yang biasa diberikan dan berusaha memberikan kinerja melebihi dari seperti yang diharapkan (Wibowo, 2007). Penelitian Kristianto (2010) dan Devi (2009) juga menghasilkan kesimpulan bahwa kepuasan kerja memiliki pengaruh positif terhadap kinerja karyawan.

Komitmen organisasi juga merupakan salah satu faktor penting terhadap peningkatan kinerja karena 
berpengaruh kepada jumlah keluar masuknya karyawan dan berhubungan dengan kinerja dengan anggapan bahwa karyawan yang mempunyai komitmen tinggi terhadap perusahaan cenderung mengembangkan diri dan juga berupaya lebih besar mengembangkan perusahaan.

Komitmen organisasi diidentifikasikan sebagai perasaan, kesetiaan, dan pelibatan dinyatakan oleh pekerja terhadap organisasi atau unit dalam organisasi. Komitmen organisasi merupakan sikap yang ditunjukkan oleh karyawan melalui kesetiaan terhadap organisasi dan juga merupakan proses berkelanjutan bagaimana seorang anggota organisasi memberikan perhatian mereka kepada kesuksesan dan kebaikan bagi organisasinya. Dengan kata lain, karyawan yang memiliki komitmen tinggi akan juga meningkatkan kinerjanya.

Komitmen organisasi berpengaruh terhadap kinerja karyawan dalam penelitian Akbar dkk (2016), Susanti (2016) dan Stiven (2014). Walaupun dalam penelitian lain dari Hidayati dan Rahmawati (2015) didapatkan bahwa komitmen organisasi tidak berpengaruh terhadap kinerja pegawai. Terkait komitmen organisasi sebagai variabel intervening, penelitian Tenggara dkk (2016) menyebutkan bahwa budaya organisasi berpengaruh secara tidak langsung dan tidak signifikan terhadap variabel kinerja karyawan melalui variabel komitmen organisasional. Ini bertetangan dengan penelitian Stiven dkk (2014) yang menemukan bahwa terdapat pengaruh antara komitmen organisasional terhadap kinerja karyawan.

Penelitian ini mengambil objek di sekolah Springfield Cibubur yang merupakan sebuah sekolah Satuan Pendidikan Kerjasama (SPK) berlokasi di Propinsi Jawa Barat dengan jumlah karyawan sebanyak 60 karyawan. Sekolah SPK adalah sebuah lembaga sekolah yang menggunakan kurikulum asing dan dipadukan dengan kurikulum nasional dalam proses belajar mengajar mereka.

Penelitian ini dilakukan berdasarkan tiga alasan yaitu : (1) adanya tingkat keterlambatan karyawan yang tinggi; (2) adanya tingkat ketidakhadiran kerja yang tinggi; (3) rendahnya kekompakan kerja antara karyawan.

Terindikasi banyak karyawan sekolah Springfield yang melanggar aturan kedisiplinan yang sudah ditetapkan sekolah, mulai dari datang terlambat hingga ketidakhadiran. Tingginya tingkat keterlambatan menyebabkan lebih dari dua puluh karyawan mendapatkan surat peringatan dari sekolah tiap tahunnya sebagai sarana untuk memperbaiki kedisiplinan mereka.

Absensi, menurut aturan sekolah dinilai tidak baik apabila melebihi lima hari ketidakhadiran selama satu tahun ajaran, sedangkan keterlambatan dinilai tidak baik apabila total jam terlambat melebihi akumulasi empat jam selama satu tahun ajaran. Pada tahun ajaran 2015/2016, total keterlambatan karyawan adalah sebesar $42 \%$ dari jumlah karyawan dan meningkat menjadi sebesar 62\% di tahun ajaran 2016/2017 dan terjadi perbaikan setelah adanya surat peringatan yang dikeluarkan oleh HRD.

Berdasarkan observasi peneliti terhadap sekolah Springfield, ketidakpuasan kerja terjadi dikarenakan ketidakadaan hadiah (reward) yang diterima karyawan melalui penilaian kinerja. Karyawan cenderung mengeluh dengan aturan-aturan yang ditetapkan oleh yayasan (pemilik sekolah) sehingga karyawan cenderung melakukan pelanggaran mulai dari datang terlambat hingga ketidakhadiran. 
Lebih lanjut dengan hasil observasi, permasalahan yang muncul antara lain sistem hukuman melalui pemotongan gaji karyawan bagi keterlambatan dan ketidak hadiran tersebut yang diindikasikan tidak membantu perbaikan kinerja karyawan. Penghargaan untuk karyawan yang hadir tepat waktu waktu dan berusaha selalu hadir dalam pekerjaan juga tidak dirasakan ada. Tidak adanya penilaian kinerja yang berpengaruh terhadap kompensasi, diindikasikan dapat mempengaruhi kepuasan kerja karyawan yang dapat mempengaruhi komitmen mereka terhadap sekolah. Izin meninggalkan pekerjaan untuk beberapa waktu pada jam sekolah juga diperhitungkan langsung terhadap pemotongan gaji sehingga banyak karyawan lebih memilih untuk tidak hadir bekerja dibandingkan mengajukan ijin meninggalkan pekerjaan.

Dari observasi lanjutan peneliti, terdapat indikasi ketidakkompakan antar sesama karyawan yang terlihat dengan adanya konflik antar individu dan terbentuknya kelompok-kelompok yang juga menyebabkan munculnya konflik antar kelompok. Hal ini menyebabkan tiap-tiap kelompok memiliki kecenderungan untuk mengutamakan kepentingan kelompok daripada kepentingan organisasi yang pada akhirnya menghambat kinerja organisasi. Kurangnya koordinasi dan komunikasi serta munculnya konflik internal pada organisasi berdampak terganggunya pencapaian hasil kerja yang berkualitas dan tepat waktu.

Penelitian ini memfokuskan untuk melihat kinerja karyawan yang terlihat menurun pada tahun ajaran 2015-2018 dengan indikasi keterlambatan, ketidakhadiran karyawan, dan kekurangkompakan.
Analisis kinerja ini ditinjau melalui variabel budaya organisasi dan variabel kepuasan kerja serta variabel komitmen organisasi yang menjadi variabel intervening dalam penelitian ini. Hipotesanya adalah dengan meningkatnya budaya organisasi dan kepuasan kerja dihasilkan peningkatan kinerja karyawan. Penerapan budaya organisasi yang sesuai, kepuasan kerja karyawan yang optimal dan didukung dengan komitmen organisasi yang kuat akan menghasilkan peningkatan kinerja karyawan, sehingga tujuan organisasi dapat tercapai.

\section{TUJUAN PENELITIAN}

Untuk membuktikan ada atau tidaknya pengaruh budaya organisasi dan kepuasan kerja terhadap kinerja dengan komitmen organisasi sebagai variabel intervening pada sekolah Springfield Cibubur

\section{TELAAH LITERATUR DAN PENGEMBANGAN HIPOTESIS \\ Budaya Organisasi}

Budaya organisasi adalah penjelasan mengenai pengalaman bersama yang dialami oleh orang-orang dalam suatu organisasi tertentu. Budaya sebagai variabel independen yang berpengaruh terhadap perilaku anggota dalam meningkatkan kinerja mereka dan organisasi. Budaya organisasi adalah sifat-sifat yang memberikan nilai-nilai pada suatu organisasi, sehingga organisasi memiliki ciri khas yang membedakan dengan organisasi lain. Budaya organisasi memiliki artian sekumpulan keyakinan yang diakui bersama, sikap dan tata hubungan serta anggapan-anggapan yang secara langsung atau tidak langsung dapat diterima dan digunakan oleh seluruhan 
anggota organisasi guna mencapai tujuantujuan organisasi.

Dalam penelitian yang dilakukan oleh Robbins (2008) mengenai budaya organisasi digunakan indikator dan instrumen pengukuran sebagai berikut :

1. Inovasi dan pengambilan resiko, berkaitan dengan sampai mana para anggota organisasi/karyawan didorong untuk inovatif dan berani mengambil risiko, yang diukur dengan 4 instrumen berikut :
a. Dukungan dan suasana kerja terhadap kreativitas
b. Penghargaan terhadap aspirasi organisasi
c. Pertimbangan anggota organisasi dalam mengambil keputusan
d. Tanggung jawab anggota organisasi

2. Perhatian dan rincian yang berkaitan dengan sejauh mana para anggota organisasi/ karyawan diharapkan mau memperlihatkan kecermatan (presisi), analisis dan perhatian kepada rincian, yang diukur dengan 2 instrumen berikut :
a. Ketelitian dalam bekerja
b. Evaluasi kinerja

3. Orientasi hasil, menggambarkan sejauh mana manajemen fokus pada hasil daripada teknik dan proses yang digunakan untuk mendapatkan hasil tersebut, yang diukur menggunakan 2 instrumen sebagai berikut :
a. Target yang dicapai
b. Fasilitas kerja

4. Orientasi manusia, menjelaskan bagaimana dampak keputusan manajemen memperhitungkan efek kepada orang-orang di dalam organisasi tersebut, yang diukur dengan 3 instrumen berikut:
a. Perhatian organisasi untuk kenyamanan kerja karyawan
b. Perhatian organisasi terhadap rekreasi
c. Perhatian organisasi terhadap keperluan pribadi karyawan

5. Orientasi tim, ditujukkan dengan sejauh mana kegiatan kerja organisasi dilaksanakan dalam tiap team kerja, bukan pada individu-individu, yang diukur dengan 2 instrumen berikut:
a. Kerjasama antara anggota organisasi
b. Toleransi antara anggota organisasi

6. Agresifitas, menunjukkan sejauh mana orang-orang dalam organisasi memberikan keagresifan dan kompevitas dan bukan bersantai dalam bekerja, yang diukur dengan 3 instrumen berikut :
a. Kebebasan untuk memberikan saran
b. Iklim persaingan dalam organisasi
c. Kemauan karyawan dalam usaha peningkatan diri

7. Stabilitas, sejauh mana kegiatan organisasi menekankan dipertahankannya status quo sebagai lawan dari pertumbuhan untuk berinovasi, yang diukur dengan 2 instrumen berikut :
a. Dukungan organisasi dalam mempertahankan status quo
b. Stabilitas kerja

\section{Kepuasan Kerja}

Kepuasan kerja adalah sikap seseorang terhadap pekerjaannya, yang memperlihatkan perbedaan antara jumlah penghargaan yang diterima pekerja dan jumlah yang mereka meyakini seharusnya mereka mendapatkan (Robbins, 2008). Gibson, Ivancevich, dan Donelly (2000:106) menyatakan kepuasan kerja sebagai sikap yang dimiliki pekerja terhadap pekerjaan mereka. Sementara itu, Vecchio (1995) 
menyatakan kepuasan keja sebagai pikiran, perasaan, dan tindakan seseorang, yang menunjukkan sikap seseorang terhadap pekerjaannya.

Robin dan Judge dalam Puspitawati (2013) menernagkan kajian atas kepuasan kerja dengan menggunakan indikator dan instrumen pengukuran sebagai berikut :

1. Pekerjaan itu sendiri (work it self), yaitu sumber utama kepuasan dimana pekerjaan tersebut diberikan tugas yang menarik, kesempatan untuk belajar, kesempatan untuk bertanggung jawab dan kemajuan untuk karyawan sendiri, yang diukur dengan menggunakan 3 instrumen berikut :
a. Pemberian tugas
b. Kesempatan untuk belajar
c. Kesempatan untuk bertanggung jawab

2. Gaji/upah (pay), yaitu faktor multidimensi dalam memberikan kepuasan kerja. Sejumlah upah/uang yang diterima karyawan menjadi penilaian untuk kepuasan dimana hal ini bisa dipandang sebagai hal yang dianggap pantas dan layak. Yang digunakan sebagai pengukuran adalah 2 instrumen sebagai berikut:

a. Sistem penggajian karyawan

b. Keadilan dalam pemberian penggajian

3. Promosi (promotion), yaitu kesempatan untuk berkembang baik secara intelektual dan keahlian serta menjadi dasar perhatian penting untuk maju dalam organisasi sehingga menciptakan kepuasaan. Instrumen pengukuran yang digunakan adalah kesempatan promosi.

4. Pengawasan (supervision), yaitu kemampuan manajer untuk dapat memberikan bantuan teknis dan dukungan perilaku. Pertama adalah berpusat pada karyawan, diukur menurut tingkat dimana manajer menggunakan ketertarikan pribadi dan kepedulian terhadap karyawan. Kedua adalah iklim partisipasi atau pengaruh dalam menagmbil keputusan yang dapat berpengaruh terhadap karyawan. 2 instrumen berikut digunakan sebagai pengukuran :

a. Gaya memimpin

b. Dukungan dari atasan

5. Rekan kerja (co-workers), yaitu rekan keja yang dapat bekerjasama dan merupakan sumber kekuatan kerja yang paling sederhana. Kelompok kerja, terutama tim yang kompak dalam bertindak sebagai sumber dukungan, kenyamanan iklim kerja, nasihat, dan bantuan kepada anggota individu. Yang digunakan sebagai pengukuran adalah 2 instrumen sebagai berikut :

a. Hubungan diantara rekan kerja

b. Dukungan dari rekan kerja

\section{Kinerja}

Kinerja adalah hasil kerja baik secara kualitas dan kuantitas yang dicapai oleh seorang pegawai dalam melaksanakan tugasnya sesuai dengan tanggung jawab yang diberikan kepadanya. Definisi kinerja menurut Bambang Kusriyanto (2005 : 9) adalah membandingkan antara hasil yang dicapai dengan peran serta pekerja per satuan waktu. Lijan Poltak Sinambelan (2012) mengemukakan bahwa kinerja pegawai didefinisikan sebagai kemampuan pegawai dalam mengerjakan keahlian tertentu. Kinerja pegawai sangatlah perlu, sebab dengan kinerja ini maka akan dapat diketahui seberapa jauh kemampuan mereka dalam pelaksanakan tugas yang diberikan kepadanya. Untuk itu diperlukan penentuan kriteria yang jelas dan terukur atau Key Performance Indikator, serta ditetapkan bersama-sama 
untuk menjadi acuan. Kinerja individu didefinisikan sebagai kemampuan individu dalam melakukan pekerjaan dengan keahlian tertentu.

Mangkunegara (2011:61) menyatakan bahwa pengukuran kinerja dapat diukur dengan indikator sebagai berikut :

1. Dimensi kuantitas kerja, yaitu banyaknya jumlah jenis pekerjaan yang dilakukan dalam satu waktu sehingga efisiensi dan efektivitas dapat terlaksana sesuai dengan tujuan organisasi. Indikator ini diukur dengan menggunakan 2 buah instrumen berikut :
a. Waktu dalam menyelesaikan pekerjaan.
b. Target yang dapat dicapai.

2. Dimensi kualitas kerja, menunjukan kerapihan, ketelitian, keterkaitan hasil kerja dengan tidak menghiraukan jumlah beban pekerjaan. Kualitas kerja yang baik dapat menghindari tingkat kesalahan dalam penyelesaian pekerjaan yang bisa bermanfaat bagi kemajuan organisasi. Indikator ini diukur dengan menggunakan 3 buah instrumen berikut :
a. Kemampuan.
b. Ketrampilan.
c. Hasil kerja.

3. Dimensi kerjasama, menunjukkan kesediaan pegawai untuk dapat terlibat secara aktif dengan pegawai yang lain secara vertikal maupun horizontal baik di dalam maupun diluar pekerjaan sehingga hasil pekerjaan akan semakin baik. Indikator ini diukur dengan menggunakan 2 buah instrumen berikut :
a. Kerjasama yang terjalin dengan rekan kerja.
b. Kekompakan terhadap rekan kerja.

4. Dimensi inisiatif, menunjukkan inisiatif dari dalam diri anggota perusahaan untuk melakukan pekerjaan serta mengatasi masalah dalam pekerjaan tanpa menunggu perintah dari atasan atau menunjukan tanggung jawab dalam pekerjaan yang sudah merupakan kewajiban seorang karyawan. Indikator ini diukur dengan menggunakan 2 buah instrumen berikut :

a. Kreativitas.

b. Keinginan bekerja untuk lebih baik.

\section{Komitmen Organisasi}

Komitmen organisasi atau kesetiaan pekerja adalah tingkatan dimana pekerja mengidentifikasi dirinya sebagai bagian dari organisasi dan ingin melanjutkan secara aktif berpartisipasi didalamnya (Newstorn, 2011:223). Komitmen organisasi merupakan ukuran tentang keinginan pekerja untuk tetap dalam perusahaan di masa depan. Seberapa jauh komitmen karyawan terhadap organisasi tempat mereka bekerja sangatlah menentukan organisasi itu dalam pencapaian tujuannya. Komitmen organisasi mempengaruhi apakah pekerja tetap tinggal sebagai anggota organisasi atau meninggalkan organisasi untuk mencari pekerjaan baru.

Schermerhorn, Hunt, Osborn, dan Uhl-Bin (2010) menyatakan komitmen sebagai kesetiaan seorang individu pada organisasi. Individu dengan komitmen organisasi tinggi akan berusaha dirinya dengan sangat kuat dengan organisasi dan merasa bangga mempertimbangkan dirinya sebagai anggota organisasi.

Dimensi dan indikator yang digunakan dalam penelitian ini mengadaptasi teori yang dikemukakan oleh Allen dan Meyer (1993) dalam Eva Kris Diana Devi (2009) mengemukakan 
bahwa ada tiga komponen indikator komitmen organisasi, yaitu :

1. Affective commitment, bilamana karyawan ingin menjadi bagian dari organisasi karena adanya ikatan emosional. Pengukurannya sendiri menggunakan 3 instrumen berikut :
a. Jenjang karier
b. Rasa bangga
c. Ikatan emosional

2. Continuance commitment, bilamana karyawan bertahan pada suatu organisasi karena membutuhkan pendapatan dan keuntungankeuntungan lain, atau karena karyawan tersebut tidak menemukan pekerjaan lainnya. Pengukurannya sendiri menggunakan 4 instrumen berikut :
a. Kehilangan pekerjaan
b. Kehilangan pendapatan
c. Kehilangan lingkungan
d. Rasa rugi kehilangan karir

3. Normative commitment, yang terlihat dari nilai-nilai dalam diri karyawan. Karyawan bertahan menjadi anggota organisasi karena adanya kesadaran bahwa komitmen terhadap organisasi adalah hal yang perlu dilakukan. Pengukurannya sendiri menggunakan 3 instrumen berikut:
a. Kurang etis
b. Loyalitas
c. Baik untuk karir

\section{Kerangka Pemikiran}

Kerangka pemikiran berisi tentang penjelasan hubungan antara variabel Independent (lingkungan kerja, motivasi kerja dan disiplin kerja) dan variabel dependent (kinerja pegawai).
Gambar 1

Kerangka Pemikiran

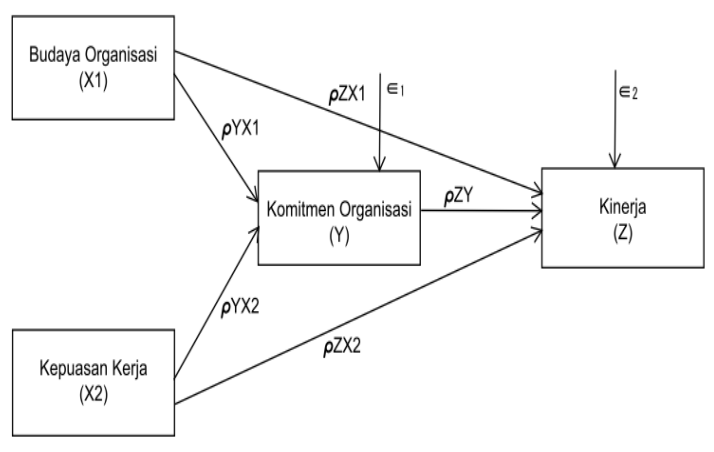

\section{METODE PENELITIAN Jenis Penelitian}

Jenis penelitian yang digunakan dalam penelitian ini adalah explanatory research tipe kausal dalam sebuah model jalur yang menguji apakah ada pengaruh antar variabel satu dengan variabel lainnya. Lingkup penelitian ini adalah menguji pengaruh budaya organisasi dan kepuasan kerja terhadap kinerja karyawan dengan komitmen organisasi sebagai variabel intervening.

\section{Variabel Penelitian}

Terdapat 4 variabel penelitian yaitu, 2 variabel independen, 1 variabel intervening, dan 1 variabel dependen. Variabel independen yang pertama yaitu budaya organisasi dengan simbol X1, variabel independen kedua yaitu kepuasan kerja dengan simbol $\mathrm{X} 2$, variabel antara (intervening) dengan simbol $Y$ dan satu variabel dependen yaitu kinerja karyawan dengan simbol $\mathrm{Z}$.

Rerangka pengaruh variabel independen, variabel intervening terhadap variabel dependen pada penelitian ini adalah sebagai berikut:

$$
\begin{aligned}
& Y=\rho Y X 1+\rho Y X 2+\in 1 \\
& Z=\rho Z X 1+\rho Z X 2+\rho Z Y+\in 2
\end{aligned}
$$




\section{Operasionalisasi Variabel}

Variabel dijelaskan dalam bentuk angket/kuesioner dengan 47 pertanyaan yang akan mewakili seluruh instrumen pengukuran yang dibutuhkan dengan kisikisi instrumentasi penelitian seperti dijelaskan dalam tabel di bawah ini.

Table 1

Kisi-kisi Instrumentasi Variabel

\begin{tabular}{|c|c|c|c|}
\hline Variabel & Indikator & Instrumen & $\begin{array}{c}\text { No. Item } \\
\text { Kuesioner }\end{array}$ \\
\hline \multirow{8}{*}{$\begin{array}{c}\text { Budaya } \\
\text { Organisasi (bo) } \\
\text { (X1) } \\
\\
\text { Sumber: } \\
\text { Robbins dan } \\
\text { Coulter (2012) }\end{array}$} & \multirow[t]{4}{*}{$\begin{array}{l}\text { 1. Inovasi dan } \\
\text { mengambil resiko } \\
\text { (bol) }\end{array}$} & $\begin{array}{l}\text { - Dukungan dan suasana } \\
\text { kerja terhadap kreativitas } \\
\text { (bo11) }\end{array}$ & 1 \\
\hline & & $\begin{array}{l}\text { Penghargaan terhadap } \\
\text { aspirasi organisasi } \\
\text { (bol2) }\end{array}$ & 2 \\
\hline & & \begin{tabular}{|l|} 
Pertimbangan anggota \\
organisasi dalam \\
mengambil resiko (bo13)
\end{tabular} & 3 \\
\hline & & 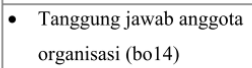 & 4 \\
\hline & \multirow[t]{2}{*}{$\begin{array}{l}\text { 2. Perhatian dan } \\
\text { rincian (bo2) }\end{array}$} & $\begin{array}{ll}\text { - } & \text { Ketelitian dalam } \\
\text { melakukan pekerjaan } \\
\text { (bo21) }\end{array}$ & 5 \\
\hline & & $\begin{array}{ll}\text { - } & \text { Evaluasi hasil kerja } \\
\text { (bo22) }\end{array}$ & 6 \\
\hline & \multirow{2}{*}{$\begin{array}{l}\text { 3. Orientasi hasil } \\
\text { (bo3) }\end{array}$} & - Pencapaian target (bo31) & 7 \\
\hline & & $\begin{array}{ll}\text { - } & \text { Dukungan lembaga } \\
\text { dalam bentuk fasilitas } \\
\text { kerja (bo32) }\end{array}$ & 8 \\
\hline & \multirow[t]{3}{*}{$\begin{array}{l}\text { 4. Orientasi manusia } \\
\text { (bo4) }\end{array}$} & $\begin{array}{l}\text { Perhatian organisasi } \\
\text { terhadap kenyamanan } \\
\text { kerja (bo41) }\end{array}$ & 9 \\
\hline & & $\begin{array}{ll} & \text { Perhatian organisasi } \\
\text { terhadap rekreasi (bo42) }\end{array}$ & 10 \\
\hline & & $\begin{array}{l}\text { Perhatian organisasi } \\
\text { terhadap keperluan } \\
\text { pribadi (bo43) }\end{array}$ & 11 \\
\hline & \multirow[t]{2}{*}{$\begin{array}{l}\text { 5. Orientasi Tim } \\
\text { (bo5) }\end{array}$} & $\begin{array}{l}\text { Kerjasama yang terjadi } \\
\text { antara anggota organisasi } \\
\text { (bo51) }\end{array}$ & 12 \\
\hline & & $\begin{array}{l}\text { - Toleransi antara anggota } \\
\text { organisasi (bo52) }\end{array}$ & 13 \\
\hline & \multirow[t]{3}{*}{ 6. Agresifitas (bo6) } & $\begin{array}{l}\text { - } \\
\text { mebebasan untuk } \\
\text { (bo61) }\end{array}$ & 14 \\
\hline & & $\begin{array}{l}\text { Iklim bersaing dalam } \\
\text { organisasi (bo62) }\end{array}$ & 15 \\
\hline & & $\begin{array}{ll} & \text { Kemauan karyawan } \\
\text { untuk meningkatkan diri } \\
\text { (bo63) }\end{array}$ & 16 \\
\hline & \multirow[t]{2}{*}{ 7. Stabilitas (bo7) } & $\begin{array}{l}\text { - Dukungan organisasi } \\
\text { dalam mempertahankan } \\
\text { status quo (bo71) }\end{array}$ & 17 \\
\hline & & $\begin{array}{l}\text { - Mempertahankan } \\
\text { stabilitas kerja (bo72) }\end{array}$ & 18 \\
\hline
\end{tabular}

\begin{tabular}{|c|c|c|c|}
\hline \multirow{10}{*}{$\begin{array}{c}\text { Kepuasan } \\
\text { Kerja (kk) } \\
\text { (X2) } \\
\\
\text { Sumber: } \\
\text { Robbins dan } \\
\text { Judge (2017) }\end{array}$} & \multirow[t]{3}{*}{$\begin{array}{l}\text { 1. Pekerjaan itu } \\
\text { sendiri }(\mathrm{kk} 1)\end{array}$} & $\begin{array}{l}\text { - Tugas yang diberikan } \\
(\mathrm{kk11})\end{array}$ & 19 \\
\hline & & $\begin{array}{ll}\text { - } & \text { Kesempatan untuk } \\
& \text { belajar (kk12) }\end{array}$ & 20 \\
\hline & & 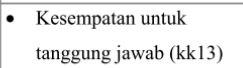 & 21 \\
\hline & \multirow[t]{2}{*}{ 2. Gaji/ Upah (kk2) } & $\begin{array}{l}\text { - Sistem penggajian } \\
(\mathrm{kk} 21)\end{array}$ & 22 \\
\hline & & $\begin{array}{l}\text { - } \begin{array}{l}\text { Keadilan penggajian } \\
(\mathrm{kk} 22)\end{array} \\
\end{array}$ & 23 \\
\hline & 3. Promosi (kk3) & - Peluang promosi (kk31) & 24 \\
\hline & \multirow[t]{2}{*}{$\begin{array}{l}\text { 4. Pengawasan } \\
(\mathrm{kk} 4)\end{array}$} & 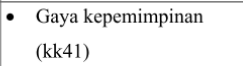 & 25 \\
\hline & & $\begin{array}{ll}\text { - } & \text { Dukungan dari pimpinan } \\
(\mathrm{kk} 42)\end{array}$ & 26 \\
\hline & \multirow[t]{2}{*}{$\begin{array}{l}\text { 5. Rekan Kerja } \\
\text { (kk5) }\end{array}$} & $\begin{array}{l}\text { - Hubungan antara rekan } \\
\text { kerja (kk51) }\end{array}$ & 27 \\
\hline & & $\begin{array}{l}\text { - Dukungan rekan kerja } \\
(\mathrm{kk52})\end{array}$ & 28 \\
\hline \multirow{9}{*}{$\begin{array}{c}\text { Kinerja (kn) } \\
\text { (Z) } \\
\text { Sumber : } \\
\text { Mangkunegara } \\
\text { (2011) }\end{array}$} & \multirow[t]{2}{*}{$\begin{array}{l}\text { 1. Dimensi kuantitas } \\
(\mathrm{kn} 1)\end{array}$} & $\begin{array}{l}\text { - Waktu dalam belajar } \\
(\mathrm{kn} 11)\end{array}$ & 29 \\
\hline & & - Pencapaian target (kn12) & 30 \\
\hline & \multirow{3}{*}{$\begin{array}{l}\text { 2. Dimensi kualitas } \\
\text { kerja }(\mathrm{kn} 2)\end{array}$} & - Kemampuan (kn21) & 31 \\
\hline & & - Ketrampilan (kn22) & 32 \\
\hline & & - Hasil kerja (kn23) & 33 \\
\hline & \multirow[t]{2}{*}{$\begin{array}{l}\text { 3. Dimensi } \\
\text { Kerjasama (kn3) }\end{array}$} & $\begin{array}{l}\text { Jalinan kerjasama } \\
\text { dengan rekan kerja } \\
(\mathrm{kn} 31)\end{array}$ & 34 \\
\hline & & 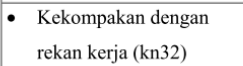 & 35 \\
\hline & \multirow{2}{*}{$\begin{array}{l}\text { 4. Dimensi Inisiatif } \\
(\mathrm{kn} 4)\end{array}$} & - Kreativitas (kn41) & 36 \\
\hline & & $\begin{array}{ll}\text { - } & \text { Keinginan bekerja untuk } \\
\text { lebih baik }(\mathrm{kn} 42)\end{array}$ & 37 \\
\hline \multirow[t]{2}{*}{$\begin{array}{c}\text { Komitmen } \\
\text { Organisasi (ko) } \\
\text { (Y) }\end{array}$} & \multirow[t]{3}{*}{$\begin{array}{l}\text { 1. Affective } \\
\text { commitment (kol) }\end{array}$} & - Jenjang karir (kol1) & 38 \\
\hline & & - Rasa bangga (ko12) & 39 \\
\hline \multirow{8}{*}{$\begin{array}{c}\text { Sumber: } \\
\text { Allen dan } \\
\text { Mayer (1993) } \\
\text { dalam Eva Kris } \\
\text { (2009) }\end{array}$} & & - Ikatan emosional (ko13) & 40 \\
\hline & \multirow[t]{4}{*}{$\begin{array}{l}\text { 2. Continuance } \\
\text { commitment (ko2) }\end{array}$} & $\begin{array}{l}\text { - Kehilangan pekerjaan } \\
(\text { ko21) }\end{array}$ & 41 \\
\hline & & $\begin{array}{ll}\text { - } & \text { Kehilangan pendapatan } \\
& \text { (ko22) }\end{array}$ & 42 \\
\hline & & $\begin{array}{ll}\text { - } & \text { Kehilangan lingkungan } \\
& (\text { ko23) }\end{array}$ & 43 \\
\hline & & $\begin{array}{l}\text { - } \begin{array}{l}\text { Rasa rugi akan karir } \\
\text { (ko24) }\end{array} \\
\end{array}$ & 44 \\
\hline & \multirow{3}{*}{$\begin{array}{l}\text { 3. Normative } \\
\text { commitment (ko3) }\end{array}$} & - Kurang etis (ko31) & 45 \\
\hline & & - Kesetiaan (ko32) & 46 \\
\hline & & $\begin{array}{l}\text { - } \begin{array}{l}\text { Baik untuk berkarir } \\
\text { (ko33) }\end{array} \\
\end{array}$ & 47 \\
\hline
\end{tabular}

\section{Metode Pengumpulan Daya}

Data dikumpulkan dengan menggunakan metode kuesioner yaitu dengan memberikan daftar pertanyaan secara langsung kepada responden. Kuesioner tersebut merupakan angket 
tertutup yang terdiri atas dua bagian, yaitu bagian pertama yang berisi pertanyaanpertanyaan untuk memperoleh data pribadi responden dan bagian kedua berupa instrumen yang digunakan untuk mendapatkan data yang mewakili indikator-indikator variabel yang dikembangkan dalam penelitian ini. Pernyataan-pernyataan didalam bagian kedua dibuat dengan menggunakan skala Likert 1-5 agar didapatkan data yang bersifat interval dan diberi nilai, untuk kategori pernyataan dari sangat tidak setuju sampai menuju sangat setuju.

\section{Metode Analisis}

Dalam penelitian ini, dilakukan analisa jalur (path analysist) dengan menggunakan analisa regresi. Sebelumnya kesahihan dan kehandalan data yang didapatkan melalui angket/kuesioner diuji melalui uji validitas dan reliabilitas.

Setelah itu uji asumsi klasik dilakukan untuk memberikan kepastian bahwa persamaan regresi yang akan didapatkan memiliki ketepatan dalam estimasi, tidak bias dan konsisten. Uji asumsi klasik yang dilakukan adalah uji normalitas (metode one-sample kolgomorov-smirnov test), uji multi-kolinieritas (metode variance inflation factor/VIF), uji heteroskedastistias (metode Glejser) dan uji autokorelasi (metode Durbin Watson).

Selanjutnya dilakukan analisa regresi menggunakan simulasi SPSS yaitu untuk mendapatkan koefisien determinasi (R2) sehingga pengaruh selurih variabel independen terhadap variabel dependen dapat diketahui, uji F untuk melihat hubungan linear variabel dependen terhadap variabel independen dan uji $t$ untuk mendapatkan seberapa besarn pengaruh variabel independen secara sendiri-sendiri/parsial terhadap variabel dependen. Dari hasil analisa regresi tersebut diatas, akan dapat ditentukan persamaan struktur dan model persamaan struktur yang sudah memunculkan nilai koefisien masing-masing variabel sesuai hasil penelitian.

Semua analisa dan pengujian diatas disimulasikan dengan menggunakan program IBM SPSS Statistics versi 23.

\section{HASIL PENELITIAN DAN PEMBAHASAN}

Penelitian ini dilakukan dengan memberikan angket kepada seluruh karyawan sekolah Springfield Cibubur dengan tidak mengikutsertakan peneliti itu sendiri. Angket diberikan kepada 59 responden dan dikembalikan kembali serta diisi lengkap oleh 59 responden.

\section{Deskripsi Responden}

Berdasarkan data yang didapatkan, diketahui bahwa sebagian besar responden berjenis kelamin perempuan sebanyak $71.2 \%$, sedangkan laki-laki sebesar $28.9 \%$.

Berdasarkan kelompok usia, terlihat kelompok usia yang terbanyak adalah 3645 tahun sebesar $47.5 \%$ diikuti kelompok usia 26-35 tahun sebesar 33.9\%, lalu kelompok usia diatas 46 tahun dan dibawah 25 tahun yang masing-masing sebesar $13.6 \%$ dan 5.1\%. Berdasarkan usia karyawan, terdapat $61.1 \%$ responden yang berusia diatas 36 tahun. Informasi ini menggambarkan bahwa dari segi usia sebagian besar karyawan sekolah Springfield Cibubur sudah berusia matang dan memiliki cukup pengalaman di bidangnya.

Berdasarkan kelompok pendidikan, kelompok pendidikan S1 yang terbanyak sebesar $66.1 \%$ diikuti kelompok pendidikan Diploma sebesar $11.9 \%$ lalu kelompok pendidikan S2 dan SMA yang masing-masing sebesar $13.6 \%$ dan $8.5 \%$. Dari segi pendidikan, terdapat $79.7 \%$ karyawan yang memiliki pendidikan 
minimal level Sarjana (S1). Hasil ini menunjukkan bahwa kualitas dan kompetensi karyawan dari sisi akademis untuk sebagian besar karyawan sudah cukup baik.

Berdasarkan pengelompokan berdasarkan lama bekerja di sekolah Springfield Cibubur, kelompok 3-6 tahun adalah yang terbanyak sebesar 39\% diikuti 6 - 9 tahun sebesar $27.1 \%$ lalu 9 - 12 tahun, dibawah 2 tahun dan diatas 12 tahun yang masing-masing sebesar $18.6 \%$, $8.5 \%$ dan $6.8 \%$. Terdapat $52.5 \%$ dari keseluruhan karyawan yang sudah bekerja di sekolah Springfield Cibubur lebih dari 6 tahun. Hasil ini menunjukkan secara umum kesetiaan karyawan terhadap organisasi cukup baik dengan anggapan sebagian besar diantaranya telah memahami secara jelas budaya organisasi dan komitmen organisasi perusahaan.

\section{Deskripsi Jawaban Responden Budaya Organisasi}

Pada variabel budaya organisasi (bo) terdapat 7 indikator yang diukur dengan 18 instrumen pertanyaan dalam kuesioner.

Secara umum, nilai rata-rata untuk variabel budaya organisasi berada antara rentang persetujuan jawaban cukup setuju (3) dan setuju (4) yaitu 3.52, dimana berdasarkan responden dapat dipandang cukup baik - menuju baik, perlu dipertahankan dan dapat ditingkatkan lebih tinggi lagi.

Dari 7 indikator untuk variabel budaya organisasi, indikator stabilitas (bo7) memiliki nilai rata-rata yang paling rendah yaitu 2.63 yang berada diantara nilai persetujuan tidak setuju (2) dan cukup setuju (3). Ini berarti untuk indikator stabilitas yang mencerminkan sejauh mana kegiatan organisasi menekankan status quo (mempertahankan apa yang ada karena dianggap sudah cukup baik) daripada pertumbuhan, indikator tersebut dinilai oleh karyawan tidak baik - menuju cukup baik, sehingga perlu ditingkatkan.

Indikator yang mendapat nilai persetujuan paling tinggi adalah indikator inovasi dan mengambil resiko (bo1) yaitu 4.04 yang berada diantara nilai persetujuan setuju (4) dan sangat setuju (5). Ini berarti, untuk indikator inovasi dan mengambil resiko tercermin sejauh mana organisasi mendorong para karyawan untuk berinovasi dan mengambil resiko serta penilaian terkait bagaimana organisasi menghargai tindakan pengambilan resiko oleh karyawan, indikator tersebut dinilai oleh karyawan baik-menuju sangat baik sehingga perlu dipertahankan.

Untuk variabel budaya organisasi, indikator-indikator diurutkan dari nilai persetujuan terendah adalah sebagai berikut : indikator stabilitas (bo7) - 2.63; indikator orientasi manusia (b04) - 3.28; indikator agresifitas (b06) - 3.30; indikator perhatian dan rincian (b02) - 3.53; indikator orientasi hasil (bo3) - 3.69; indikator orientasi tim (b05) - 3.94; dan indikator inovasi dan mengambil resiko (b01) - 4.04.

\section{Kepuasan Kerja}

Pada variabel kepuasan kerja (kk) terdapat 5 indikator yang diukur dengan 10 instrumen pertanyaan dalam kuesioner.

Secara umum, nilai rata-rata untuk variabel kepuasan kerja berada antara rentang persetujuan jawaban cukup setuju (3) dan setuju (4) yaitu 3.27, dimana menurut responden dapat dipandang cukup baik-menuju baik, perlu dipertahankan dan dapat ditingkatkan lebih tinggi lagi.

Dari 5 indikator untuk variabel budaya organisasi, indikator promosi (kk3) memiliki nilai rata-rata yang paling rendah yaitu 2.76 yang berada diantara nilai persetujuan tidak setuju (2) dan cukup setuju (3). Ini berarti untuk indikator promosi yang mencerminkan kesempatan 
untuk berkembang secara intelektual dan memperluas keahlian dan menjadi perhatian penting untuk maju dalam organisasi sehingga tercipta kepuasaan, indikator tersebut dinilai oleh karyawan tidak baik-menuju cukup baik, sehingga perlu peningkatan.

Indikator yang mendapat nilai persetujuan tertinggi adalah indikator rekan kerja (kk5) yaitu 3.92 yang berada diantara nilai persetujuan cukup setuju (3) dan setuju (4). Ini berarti, untuk indikator rekan kerja yang mencerminkan hubungan kooperatif dengan rekan kerja yang merupakan sumber kekuatan kerja yang paling sederhana; dan kelompok kerja berupa tim yang kompak bertindak yang sebagai sumber dukungan, kenyamanan, nasihat, dan bantuan kepada anggota individu, indikator tersebut dinilai oleh karyawan cukup baik-menuju baik sehingga perlu dipertahankan dan ditingkatkan.

Untuk variabel kepuasan kerja, indikator-indikator diurutkan dari nilai persetujuan terendah adalah sebagai berikut : indikator promosi (kk3) - 2.76; indikator gaji/upah (kk2) - 2.85; indikator pekerjaan itu sendiri (kk1) - 3.18; indikator pengawasan (kk4); indikator rekan kerja (kk5) - 3.92.

\section{Kinerja}

Pada variabel kinerja $(\mathrm{kn})$ terdapat 4 indikator yang diukur dengan 9 instrumen pertanyaan dalam kuesioner.

Secara umum, nilai rata-rata untuk variabel kinerja berada antara rentang persetujuan jawaban cukup setuju (3) dan setuju (4) yaitu 3.92, dimana berdasarkan responden dapat dipandang cukup baikmenuju baik, perlu dipertahankan dan dapat ditingkatkan lebih tinggi lagi.

Dari 4 indikator untuk variabel kinerja, indikator dimensi kerjasama (kn3) memiliki nilai rata-rata yang paling rendah yaitu 3.56 yang berada diantara nilai persetujuan cukup setuju (3) dan setuju (4). Ini berarti untuk indikator dimensi kerjasama yang menunjukkan kesediaan pegawai untuk berpartisipasi dengan pegawai yang lain secara vertikal dan horizontal baik di dalam maupun diluar pekerjaan sehingga hasil pekerjaan akan semakin baik, indikator tersebut dinilai oleh karyawan cukup baik-menuju baik, sehingga perlu dipertahankan dan ditingkatkan.

Indikator yang mendapat nilai persetujuan tertinggi adalah indikator dimensi kualitas kerja $(\mathrm{kn} 2)$ yaitu 4.13 yang berada diantara nilai persetujuan setuju (4) dan sangat setuju (5). Ini berarti, untuk indikator dimensi dan kualitas kerja yang mencerminkan menunjukan kerapihan, ketelitian, keterkaitan hasil kerja dengan tidak mengabaikan volume pekerjaan, indikator tersebut dinilai oleh karyawan baik-menuju sangat baik sehingga perlu dipertahankan.

Untuk variabel kinerja, indikatorindikator diurutkan dari nilai persetujuan terendah adalah sebagai berikut : indikator dimensi kerjasama (kn3) - 3.56; indikator dimensi inisiatif (kn4) - 3.92; indikator dimensi kuantitas kerja- 3.99; indikator dimensi kualitas kerja (kn2) - 4.13.

\section{Komitmen Organisasi}

Berdasarkan uji validitas, instrumen kurang etis (ko31) pada indikator normative commitment yang diwakili oleh pertanyaan kuesioner no. 45 dinyatakan kurang valid. Instrumen ko31 dinyatakan tidak valid dalam artian pertanyaan tersebut dianggap tidak mampu mengungkapkan sesuatu yang akan diukur oleh kuisioner itu sendiri. Instrumen ko31 sendiri mewakili pandangan terkait etis tidaknya meninggalkan organisasi tanpa pemberitahuan terlebih dahulu. 
Berdasarkan informasi diatas, distribusi frekuensi - variabel komitmen organisasi (ko) dikonstruksikan kembali tanpa menyertakan instrumen tersebut (ko31).

Pada variabel komitmen organisasi (ko) terdapat 3 indikator yang diukur dengan 9 instrumen pertanyaan dalam kuesioner.

Secara umum, nilai rata-rata untuk variabel kepuasan kerja berada antara rentang persetujuan jawaban tidak setuju (2) dan cukup setuju (3) yaitu 2.89, dimana sebenarnya dapat dipandang tidak baik menuju cukup baik, perlu ditingkatkan lebih tinggi lagi.

Dari 3 indikator untuk variabel komitmen organisasi, indikator normative commitment (ko3) memiliki nilai rata-rata yang paling rendah yaitu 3.07 yang berada diantara nilai persetujuan cukup setuju (3) dan setuju (4). Ini berarti untuk indikator promosi yang mencerminkan pada kepedulian terhadap biaya berkaitan kemampuan dan ketahanan ekonomi (financial security) apabila meninggalkan organisasi, indikator tersebut dinilai oleh karyawan cukup baik-menuju baik, sehingga perlu ditingkatkan.

Indikator yang mendapat nilai persetujuan tertinggi adalah indikator affective commitment (ko1) yaitu 3.36 yang berada diantara nilai persetujuan cukup setuju (3) dan setuju (4). Ini berarti, untuk indikator mencerminkan perasaan sebagai kewajiban untuk melanjutkan kesempatan kerja dan merasa harus tetap berada di organisasi, indikator tersebut dinilai oleh karyawan cukup baik-menuju baik sehingga perlu dipertahankan dan ditingkatkan.

Untuk variabel komitmen organisasi, indikator-indikator diurutkan dari nilai persetujuan terendah adalah sebagai berikut : indikator continuance commitment (ko2) - 3.06; indikator normative commitment (ko3) - 3.3; indikator affective commitment (ko1) 3.36 .

\section{Analisis Jalur}

Untuk analisis jalur dalam penelitian ini digunakan dua kali analisa regresi untuk dua sub struktur sebagai berikut:

Analisa sub struktur 1, untuk persamaan struktural

$Y=\rho Y X 1+\rho Y X 2+\in 1$

Analisa sub struktur 2, untuk persamaan struktural

$$
Z=\rho Z X 1+\rho Z X 2+\rho Z Y+\in 2
$$

Dari hasil simulasi dan analisa yang dilakukan, dikonstruksikan model persamaan struktur gabungan untuk penelitian ini dapat digambarkan dalam model di bawah ini.

\section{Gambar 2}

Model Persamaan Struktur Gabungan

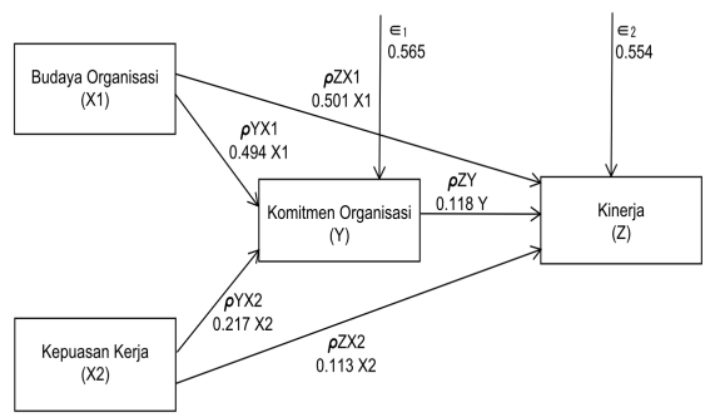

Berikut ditampilkan tabel pengaruh dan besar pengaruh antar variabel dalam penelitian ini.

Tabel 2

Pengaruh dan besar pengaruh antar variabel

\begin{tabular}{|c|c|c|c|c|}
\hline & Pengaruh & Langsung & $\begin{array}{c}\text { Tidak } \\
\text { Langsung }\end{array}$ & $\begin{array}{c}\text { Total } \\
\text { Pengaruh }\end{array}$ \\
\hline $\mathrm{X} 1 \rightarrow \mathrm{Z}$ & $\mathrm{Ya}$ & 0.501 & 0.058 & 0.559 \\
\hline$x 2 \rightarrow Z$ & Tidak & 0.113 & 0.025 & 0.138 \\
\hline$X 1 \rightarrow Y$ & Ya & 0.494 & - & 0.494 \\
\hline$X 2 \rightarrow Y$ & Tidak & 0.217 & - & 0.217 \\
\hline$Y \rightarrow Z$ & Tidak & 0.118 & - & 0.118 \\
\hline $\begin{array}{l}\text { X1 : } \\
\text { X2 : } \\
\text { Y : } \\
\text { Z : }\end{array}$ & \multicolumn{4}{|c|}{$\begin{array}{l}\text { Budaya Organisasi } \\
\text { Kepuasan Kerja } \\
\text { Komitmen Organisasi } \\
\text { Kinerja }\end{array}$} \\
\hline
\end{tabular}


1. Pengaruh budaya organisasi terhadap kinerja

Sesuai hasil uji $t$ untuk analisa regresi sub struktur 2, didapatkan hasil $t$ hitung variabel budaya organisasi (X1) $>t$ tabel atau $(3.304>2.00247)$ dengan nilai signifikansi lebih kecil dari nilai probabilitas atau $0.002<0.05$. Hal ini menunjukkan bahwa budaya organisasi (X1) mempunyai pengaruh terhadap kinerja $(Z)$. Nilai pengaruh $(\beta)$ langsung dari $X 1$ terhadap $Z$ sendiri adalah $0.501 \mathrm{X} 1$.

2. Pengaruh kepuasan kerja terhadap kinerja

Sesuai hasil uji $t$ untuk analisa regresi sub struktur 2, didapatkan hasil $t$ hitung variabel kepuasan kerja $(\mathrm{X} 2)<\mathrm{t}$ tabel atau $(0.811<2.00247)$ dan nilai signifikansi lebih besar dari nilai probabilitas atau $0.421>0.05$ hal ini menunjukkan bahwa kepuasan kerja (X2) tidak mempunyai pengaruh terhadap kinerja $(Z)$. Nilai pengaruh $(\beta)$ langsung dari $X 2$ terhadap $Z$ sendiri adalah $0.113 \times 2$.

3. Pengaruh budaya organisasi terhadap komitmen organisasi

Sesuai hasil uji $t$ untuk analisa regresi sub struktur 1, didapatkan hasil $\mathrm{t}$ hitung variabel budaya organisasi (X1) $>\mathrm{t}$ tabel atau $(3.610>2.00247)$ dan nilai signifikansi lebih kecil dari nilai probabilitas atau $0.001<0.05$. Hal ini menunjukkan bahwa budaya organisasi (X1) mempunyai pengaruh terhadap komitmen organisasi $(Y)$. Nilai pengaruh $(\beta)$ langsung dari $X 1$ terhadap Y sendiri adalah $0.494 \mathrm{X} 1$.

4. Pengaruh kepuasan kerja terhadap komitmen organisasi

Sesuai hasil uji $t$ untuk analisa regresi sub struktur 1, didapatkan hasil $t$ hitung variabel kepuasan kerja $(\mathrm{X} 2)<\mathrm{t}$ tabel atau $(1.584<2.00247)$ dan nilai signifikansi lebih besar dari nilai probabilitas atau $0.119>0.05$. Hal ini menunjukkan bahwa kepuasan kerja (X2) tidak mempunyai pengaruh terhadap komitmen organisasi $(\mathrm{Y})$. Nilai pengaruh $(\beta)$ langsung dari $X 2$ terhadap Y sendiri adalah $0.217 \mathrm{X} 2$.

5. Pengaruh komitmen organisasi terhadap kinerja

Sesuai hasil uji t untuk analisa regresi sub struktur 2, didapatkan hasil t hitung variabel komitmen organisasi $(\mathrm{Y})<\mathrm{t}$ tabel atau $(0.886<2.00247)$ dan nilai signifikansi lebih besar dari nilai probabilitas atau $0.380>0.05$. Hal ini menunjukkan bahwa komitmen organisasi (Y) tidak mempunyai pengaruh terhadap kinerja (Z). Nilai pengaruh $(\beta)$ langsung dari $\mathrm{Y}$ terhadap $\mathrm{Z}$ sendiri adalah $0.118 \mathrm{Y}$.

6. Pengaruh budaya organisasi melalui komitmen organisasi terhadap kinerja Diketahui pengaruh langsung yang diberikan X1 terhadap Z sebesar 0.501 . Sedangkan pengaruh tidak langsung X1 melalui $Y$ terhadap $\mathrm{Z}$ adalah perkalian antara nilai beta $X 1$ terhadap $Y$ dengan nilai beta $Y$ terhadap $Z$ yaitu : $0.494 \times 0.118=0.058$. Maka pengaruh total yang diberikan $\mathrm{X} 1$ terhadap $\mathrm{Z}$ adalah pengaruh langsung ditambah dengan pengaruh tidak langsung yaitu : $0.501+0.058=0.559$. Berdasarkan hasil perhitungan di atas diketahui bahwa nilai pengaruh langsung sebesar 0.501 dan pengaruh tidak langsung sebesar 0.058 yang berarti bahwa nilai pengaruh langsung lebih besar dibandingkan dengan nilai pengaruh tidak langsung, hasil ini menunjukkan bahwa budaya organisasi (X1) secara tidak langsung melalui komitmen organisasi $(\mathrm{Y})$ tidak mempunyai pengaruh terhadap kinerja karyawan (Z). 
7. Pengaruh kepuasan kerja melalui komitmen organisasi terhadap kinerja Diketahui pengaruh langsung yang diberikan X2 terhadap Z sebesar 0.133. Sedangkan pengaruh tidak langsung X2 melalui $\mathrm{Y}$ terhadap $\mathrm{Z}$ adalah perkalian antara nilai beta $X 2$ terhadap $\mathrm{Y}$ dengan nilai beta $\mathrm{Y}$ terhadap $\mathrm{Z}$ yaitu $: 0.217 \times 0.118=0.025$. Maka pengaruh total yang diberikan $\mathrm{X} 2$ terhadap $\mathrm{Z}$ adalah pengaruh langsung ditambah dengan pengaruh tidak langsung yaitu : $0.113+0.025=0.138$. Berdasarkan hasil perhitungan di atas diketahui bahwa nilai pengaruh langsung sebesar 0.133 dan pengaruh tidak langsung sebesar 0.025 yang berarti bahwa nilai pengaruh langsung lebih besar dibandingkan dengan nilai pengaruh tidak langsung, hasil ini menunjukkan bahwa kepuasan kerja (X2) secara tidak langsung melalui komitmen organisasi (Y) tidak mempunyai pengaruh terhadap kinerja karyawan $(\mathrm{Z})$.

\section{KESIMPULAN}

Penelitian menghasilkan model tentang pengaruh budaya organisasi dan kepuasan kerja terhadap kinerja karyawan dengan komitmen organisasi sebagai variabel intervening pada karyawan sekolah Springfield Cibubur.

Budaya organisasi dan kepuasan kerja secara gabungan memberikan pengaruh sebesar $43.5 \%$ terhadap komitmen organisasi, dengan $56.5 \%$ sisanya dipengaruhi oleh faktor lain. Sedangkan budaya organisasi, kepuasan kerja dan komitmen organisasi secara gabungan memberikan pengaruh sebesar $44.6 \%$ terhadap kinerja, dengan $55.4 \%$ sisanya dipengaruhi oleh faktor lain. Dari hasil penelitian tersebut, dapat diambil kesimpulan sebagai berikut:
1. Budaya organisasi berpengaruh terhadap kinerja karyawan sekolah Springfield Cibubur. Koefisien bernilai positif, sehingga dapat diartikan bahwa semakin baik budaya organisasi, maka semakin baik pula kinerja karyawan.

2. Kepuasan kerja tidak berpengaruh terhadap kinerja karyawan sekolah Springfield Cibubur.

3. Budaya organisasi berpengaruh terhadap komitmen organisasi karyawan sekolah Springfield Cibubur. Koefisien bernilai positif, sehingga dapat diartikan bahwa dengan meningkatnya budaya organisasi maka akan meningkat pula komitmen organisasi karyawan.

4. Kepuasan kerja tidak berpengaruh terhadap komitmen organisasi karyawan sekolah Springfield Cibubur.

5. Komitmen organisasi tidak berpengaruh terhadap kinerja karyawan sekolah Springfield Cibubur.

\section{DAFTAR PUSTAKA}

Adhika, Vega Isma; Rodhiyah; Hidayat Wahyu. (2014). Pengaruh Budaya Organisasi dan Komitmen Organisasi terhadap Kinerja Karyawan (Studi pada PT. Suara Merdeka Press Semarang). Semarang : Jurnal IImu Administrasi Bisnis, Vol. 3, No. 2.

Akbar, Firmananda Hutama; Hamid, Djamhur; Djudi, Mochammad. (2016). Pengaruh Kepuasan Kerja terhadap Komitmen Organisasional dan Kinerja Karyawan (Studi pada Karyawan Tetap PG Kebon Agung Malang). Malang : Jurnal Administrasi Bisnis (JAB) Universitas Brawijaya, Vol. 38 No. 2, September 2016.

Devi, Eva Kris Diana. (2009). Analisis Pengaruh Kepuasan Kerja dan Motivasi terhadap kinerja dengan 
Komitmen Organisasional sebagai Variabel Intervening (Studi pada Karyawan Outsourcing PT. Semeru Karya Buana Semarang). Semarang. Tesis : Program Pascasarjana UNDIP.

Gibson, JL. ; Ivancevich, JM ; \& Donnelly, JH. (2000). Organisasi : PerilakuStruktur-Proses. Terjemahan Organizational: Behavior-StructureProcesses (1996). Jakarta : Binarupa Aksara.

Hidayati, Tetra; Rahmawati. (2015). Pengaruh Kepuasan Kerja terhadap Komitmen Organisasi dan Kinerja Pegawai serta Kinerja Layanan (Studi pada Layanan Kesehatan Puskesmas di Kalimantan Timur). Jurnal Dinamika Manajemen (Proceeding Madic 2015), Fakultas Ekonomi Universitas Mulawarman, Samarinda-Indonesia

Krisdiyanto, Ardhyan. (2010). Analisis Faktor-faktor yang Mempengaruhi Motivasi dan Pengaruhnya terhadap Peningkatan Kinerja Karyawan. Jurnal Ilmu Ekonomi ASET, Vol 12, No 1

Kusriyanto, Bambang. (1991). Meningkatkan Produktivitas Karyawan. Jakarta : PT. Pustaka Binaman Pressindo.

Mangkunegara, Anwar Prabu. (2011). Manajemen Sumber Daya Manusia Perusahaan. Bandung : Remaja Rosdakarya.

Mulyanto, Heru; Wulandari, Anna. (2010). Penelitian : Metode \& Analisis. Semarang : CV Agung.

Pratama, Riski Syandri. (2016). Pengaruh Budaya Organisasi dan Komitmen Organisasi terhadap Kinerja Organisasi pada Pusat Pelaporan dan Analisis Laporan Kevangan (PPATK). Tesis. Program Pasca Sarjana Magister Manajemen, Universitas Lampung.

Puspitawati, N. M. D. (2013). Kepuasan Kerja dan Komitmen Organisasional
: Pengaruhnya terhadap Layanan Hotel Bali Hyatt Sanur. Tesis Program Magister Manajemen. Universitas Udayana, Denpasar, Indonesia.

Robbins, S. (2008). Perilaku Organisasi, Jilid I dan II, alih Bahasa : Hadyana Pujaatmaja. Jakarta: Prenhallindo.

Robbins, P.; Stephen dan Mary Coulter. (2010). Manajemen, diterjemahkan oleh Bob Sabran, Wibi Hardani. Erlangga : Jakarta.

Schermerhorn, John R.; Hunt, J.; Osborn, J. G.; Uhl-Bien, M. (2010). Organizational Behavior 11 th edition. USA : John Wiley \& Sons Inc. Sinambela, Lijan Poltak. (2012). Kinerja Pegawai. Graha Ilmu: Yogyakarta.

Stiven, Frangky ; Sutama, Cogito Dino ; Santoso, Thomas. (2014). Analisis Pengaruh Kepuasan Kerja Karyawan terhadap Kinerja Karyawan Melalui Komitmen Organisasional di Kowloon Palace Internasional Restaurant Surabaya. Jurnal Hospitality dan Manajemen Jasa Universitas Kristen Petra Surabaya, Vol. 2 No. 2

Susanti; Palupiningdyah. (2016). Pengaruh Kepuasan Kerja dan Komitmen Organisasi terhadap Kinerja Karyawan dengan Turnover Intention sebagai Variabel Intervening. Management Analysis Journal 5 (1) (2016). Universitas Negeri Semarang.

Tenggara, Bayu Ratno ; Hulmansyah, Huda, Nurul. (2016). Analisis Pengaruh Kepemimpinan terhadap Budaya Organisasi, Komitmen Organisasional dan Kinerja Karyawan Bank Syariah Mandiri di Jakarta. Journal of Economics and Business Aseanomics (JEBA) Vol. 1 No. 1.

Vecchio, Robert P. (1995). Organizational Behaviour. Florida : The Dryden Press.

Wibowo. (2007). Manajemen Kinerja. Jakarta : PT. Raja Grafindo Parsada 